\title{
Robin Munro on Nigel Wells
}

There's a poem I like to introduce at readings. It starts with listening to a Gaelic singer in the city of Aberdeen and experiencing some kind of recognition. I know the sense of her singing without any translation. I want people to try to get the same kind of understanding from poetry. Below (or above?) logic there is a feeling and this feeling is wholly valid.

All good poems must work on this level. They may do it by a collection of facts for the reader to associate, or by an onslaught of sensory material, or even by a statement. So long as there are spaces, what you can create there is rich and plentiful. I enjoy a good clear track through a forest, but I also value the sight of the undergrowth, where my dog finds out hidden concepts with his keen nose. For my part I create imagined depths.

There are plenty of these spaces to shout through in "A Green Man," spaces full, of pulsating life. The track is not always certain, we seem to have been plunged right into the undergrowth, without protective clothing. This is deliberate, and it would be a pity to use criticism as a bulldozer.

The elements of the poem are clear, the elements of green experience. The words associate into strong senses and images, from the first fumbling within the earth to the delight in motion.

The movement of the poem follows this. I'd like to read it pushing or feeling its way down a long page (I read a typescript). We are catching glimpses (if glimpses could be understood for all the senses). We pick up moments of this living. Life is insisting up from the dark, a kind of genesis, I feel, or kama, the original urge. I enjoy this involvement with the natural world, a close-up earthy integration. Not so much pantheism as monism-the oneness of life. This is what I reap from a poem that I have no wish to follow in a strictly logical way. Remember the Gaelic singer.

I like being pulled through this green world, recoiling from or entering into aspects of it, with all my senses and thoughts stimulated till they react like flesh.

The most important thing-says the Moravian poet Jan Skacel-is to have the heart of a child. To have it, by implication, with an adult's intellect and compassion. Within the craft and sullen art it is hard, very hard, to present the wild and instinctive and keep it wild. Indulgent poets, children, would-be poets, maybe these folk can do it. But for an accomplished poet it is hard to hold the instant in a poem, and it is all the more successful when he achieves it.

There is no doubt for me that Wells does catch the wild subconscious life. I know that from my reaction to the poem, the way my mind moves with a breath of wind along unexpected lines. And there is no doubt 
from the high degree of control and stylistic intricacy that he is nothing less than a master craftsman.

Sometimes the phrases have a turn to them like dialect or a child's speech. The strange wildness is even in the style-the odd, but pleasing, syntax of the last three lines of each section. The most pleasing is in the last section, finishing with "He grow rare but he grow God-green." I like that. I wouldn't be surprised if it was "heard" speech. I get a very vivid understanding from it; I neither care to analyze the understanding nor speculate whether it's the poet's intention. Coming back to the Gaelic song again, there is a kind of truth that is best left to itself, respected. To analyse it would be like detailing a rose or a roe deer.

Enough to say that a sense, with or without body, squirms and moles and sprints and grows. Vividly. The question must only be whether Wells indulges too far, allows his technique to embrace too much, in order to create the impression.

I suppose a critic should argue that out, then decide. I decide first, then I'll argue. Simply, my instinct tells me to enjoy the poem as a breathing creature. And if literary criticism changed my mind, it would be more dangerous than I thought. I don't like vivisection inside or outside ICI. However, I will delicately touch Nigel Wells' style and earn my critical bread.

English poetry is often too dry for me, too cerebral, too scared to take chances with sound and syllable and sentence. Dylan Thomas is still suspected of singing and disdained for his love affair with words. Wells has (from these poems) a joy in language, in the intercourse of words, in sympathetic sounds. It's not so much the mechanics of poetry as the coordinated living body of it.

There is a sensory richness in all the words. I wouldn't care to read an entire collection of such rieh fare, but I welcome a diet that includes "wonderwood flares," "needley mould," "treefully leap," "whispery wood" and so on. The real test of elaborate language is whether or not it achieves a clearer picture than the spare speech more suited to our present tastes. Here I think it does. "The falling and fallen and felled" has somehow the ritual of the wood. The "spacey place" has the childlike ring to it, the animal way of looking at things, and perhaps it couldn't be conveyed in any other way. "Some stiff of a suddenly starts ..." has a sense of the spontaneous, the breath, the momentary idea. The fact is-none of Wells' created phrases can be paraphrased. That is the justification.

It is difficult to run a poet to earth on two poems, but it seems that this rich style is a distinguishing feature of Nigel Wells. If a poet has a character and originality, that is both his strength and the greatest danger to him-the danger that he will overstate his poetic character, be too like himself, repeat himself, produce pastiche of himself. On the other hand, 
he may find enough seams to mine with his poetic pick, sharpening it every time.

In "Saturnalia," I'm torn between enjoying the pageantry of words and wondering if they need to be so flamboyant, sometimes so self-consciously archaic, so inter-related-as when the boy is "Dolled . . . Draped ... Daubed." Even "God" has to fit in with the sounds around, but then it's not a serious deity, only the dressed-up boy in the posture.

But Saturnalia is after all a ceremony, the Feast of Fools. Everything is overdone (and for good psychological reasons). The boy is dressed as the fool-king. The words used help to suggest his overloaded clothes, his painted appearance, the archetypal significance of it all, and the fun of it. The words are elaborate, ritualistic, and sometimes light-hearted.

In both poems there's a piling on of harmonic patterns. (Perhaps they're obscure Anglo-Saxon bylaws of verse!) There are rhymes, half-rhymes, expected rhymes, and syllables sounding in harmony. A ceremony of language.

The linking of sounds in "Saturnalia" has the effect of making the poem sound chanted, ritualistic, received. It also makes the poem sound nonspontaneous, rather formal. We're in a close position to the boy-king, the heart of the Festival, but we stay detached, observing.

Why is it always "this" (lad, youth, sport, etc.)? And is "prance" there for the rhyme or is that all there is to the Festival of Fools? These are the doubts of over-close reading. Stylistic devices should work their effect almost unnoticed, and perhaps they do in this poem. There are many very beautiful uses of language to catch a concept-I particularly like "elder tree time" and the stately last verse.

"Saturnalia" is a warm poem, with an understanding of ritual and its sense. Our society loses by the replacement of such Feasts of Fools with the merely commercial holidays and the drinking events of winter. Similarly imagination is being undermined as a key part of life by the imaginationsubstitutes of the media and a soulless practicality.

Perhaps "A Green Man" counters the latter, while "Saturnalia" holds onto the ancient meaningful ritual of celebrating time and acting out an inverse society. I assume the Saturnalia described will be a tradition of former times, real or half-imagined. If such an event took place now, in most places it would be a self-conscious piece of acting, a mere indulgence.

There are intimations in both these poems of a life beyond our immediate practical understanding, and that sort of life might lead to some kind of transcendence (or, to be old-fashioned, God). The themes seem to have directed themselves on the poet (rather than the poet making a cold choice) and that is always good. They are existential celebrations. Any reflection will come out of the intensity of the present experience.

I would be interested to know if Nigel Wells, besides being intensely. 
poetic, is being entertaining, existential, or explicitly meaningful in a way I've missed. (I hope not because that would require a quite different method of communication.)

The other tentative points I want to raise are the humour (in a quiet subtle sense-perhaps "good-humour" is nearer the mark) and the accent of the poems. They sound very good read aloud. Am I right to stretch the vowels? Is there a particular local speech implied?

And finally, to comment on this exercise, I can't help feeling poems like these don't gain by analysis. They either complete a circuit in the reader's mind, or they fail to make the connection and seem wordy. In my mind, they work.

\section{Nigel Wells Replies}

It is perhaps simpler to answer an adverse criticism than a favourable one. The defensive attitude is easier to elaborate on. My basic reply to Robin Munro's criticism is, I suppose, thank you very much for your kind words, I agree with you. But one has to say more, indeed would wish to, even though an evening's talk by the fire would be more pleasant than this rather removed public reply. So I say what I can about my poems, which to start with I feel presumptuous in doing. There are so many people talking about themselves in every aspect of the media I shudder at having to number myself among them. One of the, or rather one of my, reasons in writing poetry is to save myself from this kind of thing, that is putting my thoughts down in ordinary language, where they are bared for anyone to see in all their foolishness. Poetry disguises and colours the thought and thereby makes it hopefully less boring.

Like Robin Munro I, too, create imagined depths. I take the world as I know it, or to be more precise, the bit of world I know and mix it up with the other world, the one I sense, which is prior, under and parallel to this one. What come out are poems which if successful will activate my own senses and imagination and presumably anyone else's, who is of a similar cast of mind.

Robin Munro has it in the phrase "Life is insisting up from the dark." I start with a colour picture or funny feeling from the back of the head and just write it down in words which say "I am the right word, use me." (I seldom question the word's judgment.) What it's all about is sometimes realised during the construction of the poem, sometimes much later, sometimes not at all.

"A Green Man" makes use of what seems to be a recurring theme with me, that of being born, and what's more, being born alone, then trying to work out what it is you've been born into and what to use for 
support while you're here. A Green Man decides, as do a lot, that a God is the easiest way out of the problem. That is all I can tell you of the content for it's all I know. I understand my poems but I can't explain them minutely, I can only hope there are others like Mr. Munro who will derive an understanding from them, an understanding, that is, which suits their own particular needs.

The content of "Saturnalia" is less obscure. The Saturnalia is a reasonably well-known ancient festival in which a youth of good appearance had a whale of a time for one year and was ceremoniously killed at the end of it, for the usual reason of making the crops grow, etc. The poem is actually out of context, as it is part of a sequence of eleven poems about the winter festivals starting from All Hallows and going through to Christmas. To my mind obviously it reads better within the context of that sequence.

Robin Munro's point about producing pastiche of myself is a very valid one-one that I have been made aware of by several friendly critics. I can only hope that being aware of it will reduce the possibility of it happening over much.

Why is it always "this" he asks-because the things, creatures, persons and beings I write about remain to me always rather wraith-like; I can never quite pin them down to form or face.

As regards imagination and practicality, I personally don't find that one cancels out the other; I spend most of my time doing very practical jobs and thinking about them in a very practical way, but my imagination runs happily parallel to this, an imagination which I either enjoy or recoil from. Each needs the other to make it bearable, I suppose.

Robin Munro can sleep safe in the knowledge that I am far from being "explicitly meaningful," just "intensely poetic" (God am I really-how horrible).

Anyway I would like to thank him for his comments; it is obviously pleasing to me that he derived something from the poems. Also, I am in complete agreement with his remarks on logic and analysis. like.

One final note for out-loud readers-there are no rules, say them how you

\section{Coastal Village / Robin Munro}

Between the Reath of wheat

and the caring harbour

braes resound in harebells,

dancing in drifts, persuasions

of air. 